HOW

Volume 28, Number 2, pages 121 - 140

https://doi.org/10.19183/how.28.2.564

\title{
Promotion of Critical Reading through the Use of Political Cartoons
}

\author{
Promoción de la lectura crítica por medio del uso \\ de caricaturas políticas
}

\section{Willian Alexander Mora-Menjura ${ }^{1}$}

\begin{abstract}
Critical exploration of socio-political issues has been a topic strongly carried out in English classrooms in the last decades. This article is the result of a research study that shows what the use of political cartoons reveals about the promotion of critical reading in an EFL classroom at a private university in Colombia. The study was developed with fourteen students under a qualitative case study method. Workshops, teacher journals and focus-group interviews were used to collect data. The emerging categories show the positive results of using political cartoons and the change that the students had in their thoughts and actions in both the academic and social context. In the results, the students portray how they have perceived the ELT classroom, the importance of being a critical reader of texts and contexts, and how the different activities helped them construct their own critical awareness concerning social and political issues.
\end{abstract}

Keywords: critical reading, ELT classroom, political cartoons, social awareness, socio-political issues

\section{Resumen}

La exploración crítica de cuestiones sociopolíticas ha sido un tema muy desarrollado en las aulas de inglés en las últimas décadas. El presente artículo es el resultado de una investigación que muestra lo que revela el uso de caricaturas políticas sobre la promoción de la lectura crítica en un aula de

He holds a BA in Modern Languages and an MA in Language Teaching from Universidad Pedagógica y

Tecnológica de Colombia -UPTC. Currently, he is a full-time teacher and a member of IMCLE research group in UPTC, Sogamoso Campus. His interests focused on critical literacy, curriculum design, and applied linguistics.

willian.mora@uptc.edu.co

ORCID ID: https://orcid.org/0000-0002-4446-1349

Received: April 8th, 2020. Accepted: March 26th, 2021.

This article is licensed under a Creative Commons Attribution-Non-Commercial-No-Derivatives 4.0 International License. License Deed can be consulted at https://creativecommons.org/licenses/by-nc-nd/4.0. 
inglés como lengua extranjera en una universidad privada en Colombia. El estudio se desarrolló con catorce estudiantes, bajo un método de estudio de caso cualitativo. Se utilizaron talleres, diarios de profesor y entrevistas de grupos focales para recopilar los datos. Las categorías emergentes muestran los resultados positivos del uso de caricaturas políticas y el cambio que tuvieron los estudiantes en sus pensamientos y acciones tanto en el contexto académico como social. En los resultados, los estudiantes muestran cómo han percibido el aula ELT, cuál es la importancia de ser un lector crítico de textos y contextos y cómo las diferentes actividades les ayudaron a construir su propia conciencia crítica sobre temas sociales y políticos.

Palabras clave: caricaturas políticas, lectura crítica, temas sociopolíticos, aula EII, conciencia social

\section{Introduction}

Most of the courses that English language teachers follow either at schools or universities in most Colombian educational contexts are not developed under syllabuses that take into account socio-political issues. Instead, the syllabuses in many institutions have been designed mainly to enhance grammar or communicative skills. It does not mean that these teachers only focus on these skills, but unfortunately, the material, the policies of institutions, and even tests are developed to improve the previously mentioned skills. The lack of awareness about what happens in reality starts emerging and increasing since these topics are rarely considered in the EFL classroom (Kaura \& Sidhub, 2013). Likewise, Ortega (2009) argues that sociocultural and sociopolitical issues cannot be limited to only certain subjects or spaces of formal education, but these must transcend and generate transformation processes both in the subjects and their realities.

Based on Crookes and Lehner (1998), this occurs because there is a lack of teachers' training by professional learning programs in topics related to sociopolitical issues. That is why most English language teachers would prefer focusing on only aspects related to the language, instead of teaching topics that perhaps they do not know well. It must be recognized that many institutions have currently been under a process of curricular reform in order to make programs and subjects more related to social and political issues, with transversal and interdisciplinary syllabuses. In that sense, Echeverri (2020) states that since the end of the 20th century, there has been a great push in Colombia to promote the teaching of English, but still, curriculum and policies are developed under the European framework 122 that seeks to improve proficiency particularly in terms of linguistic aspects.

Ramos and Aguirre (2011) state that universities that promote language teaching programs should foster skills in pre-service teachers in order to educate critical educators, with the idea that "teaching English is not only related to the structural aspects of the English language, but that it also accounts for the social dimension English language teaching implies" (p. 170). In that sense, Samacá (2012) highlights the importance of having a critical perspective, especially in a language teacher preparation program. She indicates how critical 
practices "provide a new opportunity for pre-service teachers to re-think their pedagogical experiences for social transformation" (p. 194). Likewise, a research study conducted by Cortés and Rativa (2015) shows the change that pedagogy in Colombia had undergone between 1980 and 1990 as a consequence of the pedagogical postulates of Paulo Freire in terms of critical pedagogy within and outside the classroom.

But, why is it important that students in general learn to read images from a critical perspective? Nowadays, we live immersed in a world where a great deal of information comes to us through technology. Currently, the information that comes to us is strongly marked by the use of images, such as cartoons, where the different messages and meanings have to be carefully read to understand our society. In that sense Dominguez (2017) indicates that texts such as advertisements, signs, cartoons, and graffiti are carefully designed to transmit and depict a social and political message. The problem appears when readers do not have enough skills to understand this kind of texts, because it may mean that the communication might be broken or interrupted or simply, the message of the author is not well perceived.

In some activities about critical reading of images developed with a group of students of an English language intermediate class at a private university in Colombia, two main difficulties were identified: first, the lack of understanding and exploration of sociopolitical issues, and second, the lack of critical reading that they were supposed to be doing on the cartoons. Thus, two main questions were used for this research study: (1) What does the use of Colombian political cartoons reveal about the promotion of critical reading, and (2) What reading strategies do students use while they are involved in the practice of SCAMS (a technique used to read cartoons)?

This study sought to promote critical reading through the implementation of political cartoons about sociopolitical issues. The study was developed under a qualitative paradigm. The research method implemented was case study with intervention. Different sources such as workshops, journals, and interviews done through the focus-group method were used to collect data. Grounded theory was the method used to analyze the collected data.

\section{Theoretical Framework}

\section{Critical Reading}

Most of the theory found about critical reading defines this ability considering written and/or print texts. Although all those definitions are a fundamental base, it is paramount to mention that the main interest of this study is focused on visual/ text political cartoons. Critical pedagogy in the education theory analyzes social, political and economic factors, as well as ideologies that lie behind any national education system and the way teachers, 
students, scholars and communities perceive education and the process of teaching and learning (Barrow \& Wood, 2007). On his part, Mclaren (2003) argues that "critical pedagogy has been a widely discussed project of educational reform that challenges students to become politically literate so that they might better understand and transform how power and privilege works on a daily basis in contemporary social contexts" (p. 65).

Considering the previous authors and relating their definitions with the main aim of this study, it is found that critical pedagogy influences in the ways of production of subjectivities, and in the process of construction and generation of sociopolitical practices (Ortega, 2009). That is to say, critical pedagogy becomes a key component in the formation of students as social, critical, and aware human beings.

In addition to what was already mentioned, another concept that contributes to this study is critical reading. Freire and Macedo (1987) state that "reading does not consist merely of decoding the written word or language; rather, it is preceded by and intertwined with knowledge of the world" (p. 29). Reading the word is perhaps a process that is mostly carried out inside the classroom. However, reading the world implies to comprehend, interpret and understand society. On his part, Hudelson (1994) claims:

Reading is a language process in which an individual constructs meaning through a transaction with a written text that has been created by symbols that represent language. [...] The interpretation is influenced by past experiences of readers, language background, and cultural framework, as well as the reader's purpose for reading. (p. 129)

Additionally, Buitrago (2010) states that critical reading:

...not only seeks to develop the ability to interpret texts, but also, the ability to perceive the connections between social conditions and reading practices, to develop a critical awareness in order to take action in learning processes. From this viewpoint, it is important to encourage this kind of reading in the English class because it allows students to reach deeper ways of understanding and thinking, to stimulate language production, and to encourage autonomy in learning processes and independence in building knowledge. (p. 28)

Through critical reading, students become readers via going beyond the single text in 124 order to investigate their reality; "this is the starting point of transformation which may develop in the long run into their choices for social change" (Short, 1993, p. 34). Wallace (2003) refers to critical reading in language education as a social and critical process where the text is the center of departure. She argues that there are very few studies based on critical reading in the ELT field. She states that for early or beginning readers, it has been seen that reading has to do with decoding texts, pronouncing words correctly or practicing language structure. On the contrary, for advanced readers, it has been seen that reading has to do with comprehension activities. 


\section{Political Cartoons}

Cartoons are designed with images, gestures, or single words or expressions that are semantically created under certain semiotic systems such as linguistic, visual, gestural, and spatial that cause cartoons to be classified within what academics name a multimodal text. Kress (2010, as cited in Michelson \& Álvarez, 2016), states that:

Multimodality is concerned with the use of several modes of communication, their relationships, and the ways they are combined in processes of communication and representation. [...] Social semiotics delves into how meanings are made and structured in processes of communication and acknowledges that semiotic acts and products are constituted and shaped through historical, cultural, and social uses of signs. (p. 236)

For Halliday and Hasan (1976), "a text is best regarded as a semantic unit; a unit not of form but of meaning" (p. 2). As these authors state, it does not have to do with the length or the form, but with the meaning. In that sense, cartoons are drawings that, besides portraying reality, are created with meaning to be understood, read, analyzed, and interpreted by others.

Neuberger and Kremar (2008, as cited in Mackay, 2017), state that "political cartoons have the ability to change people's opinions" (p. 28). This may happen because cartoonists portray a reality that sometimes people do not perceive in other sources. As these are not long texts that people have to read, the different images, expressions, gestures and short phrases are created with the intention to make people change their opinions and ways of seeing and reading their world (Ammons, King, \& Yeric, 1988).

Dougherty (2002) states that political cartoons are an excellent classroom tool to raise students' critical thinking skills and to get students into classroom discussions about topics that relate to their lives. In order to interpret and understand a political cartoon, Dougherty (2002) argues that the reader must be familiar with social and political issues as well as the cultural context, and be capable to make analytical judgements.

\section{Research Design}

This study is based on a qualitative paradigm. Bell (1993) states that qualitative research is "more concerned with understanding individuals' perceptions of the world. It seeks insight rather than statistical analysis" (p. 6). Additionally, Denzin and Lincoln (2005) claim that qualitative research involves an interpretive and naturalistic approach: "This means that qualitative researchers study things in their natural settings, attempting to make sense of, or to interpret, phenomena in terms of the meanings people bring to them" (p. 3).

The method used in this current research is a case study design with intervention. This method is used to generate an in-depth, multi-faceted understanding of a complex issue in 
its real-life context. According to Yin (2016) and Adelman et al., (1977, as cited in Nuñez \& Tellez, 2012), case study responds to the need of "analyzing a particular phenomenon in detail during a specific period and in the natural context in which it happens" (p. 56). Furthermore, Hancock and Algozzine (2006) argue that case study is highly descriptive and "it employs quotes of key participants, anecdotes, prose composed from interviews, and other literary techniques to create mental images that bring to life the complexity of the many variables inherent in the phenomenon being studied" (p. 16).

I interpreted and described the experience, taking into account Stake's (1995) suggestion. He highlights the importance of revising the results of the intervention in order to determine three phases for the development of case studies. The first phase has to do with collecting information about the initial status of the participants. The second phase refers to compiling data during the intervention. These data were compiled through different sources such as the workshops and the teacher's journals in situ. The last phase has to do with registering possible changes which occurred after the intervention.

\section{Research Problem}

The research study took place in an intermediate English language class, composed of fourteen EFL students (five males and nine females from 19 to 22 years old) at a private university in Boyacá, Colombia; all of them from the Graphic Design Program of the university. In the class, a number of activities about discussing social issues that are relevant in their local context were proposed. At the beginning, the students rejected them because it was an English language class, and they were supposed to learn about grammar, verbs, pronunciation, as the syllabus states. After I explained the importance of exploring and analyzing Colombian social topics in order to create a different society in which people can comprise part of the solution of the different problems that affect everybody, they accepted them.

The students were given a text about sociopolitical issues, but they expressed that they were not used to this kind of written texts, neither were they used to discussing these topics. As most of them belong to the Graphic Design program of the university, I used different kinds of texts and political cartoons with images, messages, and symbols. The common activity was to read them, then, discuss them in groups; the students always had the chance to express their opinions about this kind of texts. I developed the same exercise in more than three sessions; the students seemed to have little knowledge and information about the topic of each cartoon. The way they tended to read them was mainly descriptive, not in depth. This allowed me to think about two possible difficulties: first, the lack of understanding and exploration of sociopolitical issues; second, the lack of the students' critical reading on the cartoons. 
Park (2011) and Zyngier and Fialho (2010) state there is a lack of deeper understanding and critical exploration of sociocultural issues in certain fields of education, and that students hardly recognize their reality and the problems their society has. One of the reasons why this happens is that students are not exposed to this kind of issues, and when they are exposed to these topics, it seems that there is a general tendency to accept what authors of different texts state; students hardly question their opinions and representations (Kaura \& Sidhub, 2013). By the same token, Samacá (2012) recognizes that critical practices allow learners to gain social skills to actively participate in a transformed and inclusive democratic community. These authors reinforce the idea of implementing critical praxis within the classrooms, precisely because there has been little formation and exploration of these topics, which could make the process of social transformation more difficult.

According to Huang (2011), "students mainly regarded reading as a means for information-gathering and entertainment and not for social critique" (p. 145). Likewise, Bosley (2008) states that one of the problems students in higher education face concerning reading is that high schools have mostly taught students to read receptively and to read for gathering information; students have not then been taught to read actively or critically and to construct their own knowledge as they read. Furthermore, Giroux (2011, as cited in Echeverry, 2020) argues that due to the social and political orientation of critical reading "critical pedagogies should pay attention to the formative culture that takes place outside the walls of a classroom or schools, which includes media" (p. 27).

\section{Research Procedure}

In order to promote critical reading in this group of students, they were asked about the most common sociopolitical issues in their local and national contexts. They all agreed on the following topics: corruption, education, minimum wage, peace, and poverty. After knowing the topics, the search and selection of specific cartoons started. Once the first workshop was created and applied, the researcher, author of this current research article, considered the students' opinions in order to design the next workshops.

For the design of each workshop, different activities, based on Bloom's taxonomy (1956), were considered from the level of difficulty of the activities; that is to say, in the first two workshops, the students developed a number of basic activities by enhancing lower-order thinking skills (as remembering, understanding, and applying); in the other two subsequent workshops, they were asked to develop more complex exercises to improve higher-order thinking skills (as analyzing, evaluating, and creating).

The four workshops were designed and applied throughout eleven weeks in one academic semester. To analyze cartoons critically, a technique called SCAMS, proposed by Martínez (2011), was implemented. The students applied this technique in the second and 
third workshop. In the last workshop, the students did not apply this technique, because the researcher wanted to know how much they had learned about analyzing cartoons critically.

In 2011, Martínez proposed a technique named SCAMS to analyze cartoons critically. Each one of the letters stands for a different purpose.

- Subject: The readers are asked to identify the topic of the cartoon.

- Caption: The author suggests that the readers should recognize what the titles of the cartoons are, not only for identifying them, but for recognizing what their meanings are.

- Actions: The readers recognize all that is happening; in other words they describe movements, actions, and dialogues as well as what the characters are doing, thinking, or saying.

- Messages/theme: Perhaps this is one of the most complex steps, since the readers are asked to recognize what the author's point of view is, what the theme of the cartoon is, and what the purpose for making the cartoon is.

- Symbols: With this step, semiotics is remarkable since the readers are asked to analyze different aspects of the semiotic systems such as single letters, the size of the words, signs, images, body language, gestures, facial expressions, colors, and the position of certain elements.

The following table describes the sociopolitical topics selected to design the workshops, whether SCAMS was applied or not, and the different processes that the students carried out during the implementation.

Table 1. Workshops (WS)

\begin{tabular}{|c|c|c|c|}
\hline WS & Topic & Objective & Cognitive Processes \\
\hline 1 & Education & $\begin{array}{l}\text { To engage students with } \\
\text { vocabulary and questions related } \\
\text { to social and political aspects. }\end{array}$ & $\begin{array}{l}\text { Matching words, identifying and learning } \\
\text { vocabulary, describing cartoons, learning } \\
\text { about the topic, giving points of view. }\end{array}$ \\
\hline 2 & Corruption & $\begin{array}{l}\text { To implement SCAMS to analyze } \\
\text { social and political cartoons. }\end{array}$ & $\begin{array}{l}\text { Remembering vocabulary, relating words, defining } \\
\text { concepts, understanding the topic, giving points of } \\
\text { view, interpreting information, understanding and } \\
\text { applying SCAMS, analyzing and evaluating cartoons. }\end{array}$ \\
\hline 3 & $\begin{array}{l}\text { Minimum } \\
\text { wage/ Peace }\end{array}$ & $\begin{array}{l}\text { To analyze cartoons through SCAMS } \\
\text { and to create my own cartoon. }\end{array}$ & $\begin{array}{l}\text { Applying SCAMS, interpreting information, } \\
\text { analyzing and evaluating messages, giving } \\
\text { points of view, creating cartoons. }\end{array}$ \\
\hline 4 & $\begin{array}{l}\text { Education, } \\
\text { poverty and } \\
\text { corruption }\end{array}$ & $\begin{array}{l}\text { To analyze cartoons, to relate them } \\
\text { with my own context, and to portray } \\
\text { my own perspective of my reality. }\end{array}$ & $\begin{array}{l}\text { Remembering and using previous information, } \\
\text { interpreting information, analyzing and evaluating } \\
\text { messages, giving points of view, creating } \\
\text { cartoons, relating and comparing information } \\
\text { with their own local and national contexts. }\end{array}$ \\
\hline
\end{tabular}


As a final product, in the last week, the students were asked to write a short reflective text in which they expressed how useful the process was with the implementation of workshops and the use of political cartoons to promote critical reading.

\section{Data Collection Strategies}

\section{Students' Artifacts}

This is a tool to interpret and assess students' performance (McMillan \& Schumacher, 2000). Also, these are "the range of written and symbolic records kept by or on participants in a social group" (Goetz \& Lecompte, 1984, as cited in Merriam, 1991, p.105). The following artifacts were used in the current study:

- Workshops in which the students had to develop different activities such as describing and creating images, giving points of view, defining concepts, analyzing the local and national situation, and answering questions about sociopolitical topics portrayed in political cartoons.

- A final reflection paragraph, in which the students were asked to write a passage about the use of SCAMS and the implementation of the political cartoons in the workshops. They developed this task at the end of the process.

\section{Teacher Journal}

In vivo journals were used to register the different ideas, knowledge, and opinions that the students had while engaged in the development of the different activities. Freeman (1998) states that journals are useful instruments to record thoughts, reflections, and different aspects that researchers observe in their researched population.

\section{Focus Group}

This method allows one to know and study the different opinions and attitudes of a determined public. Commonly, it is associated with interviews, although the researcher (moderator) does not ask direct questions of a specific participant (Yin, 2016).

I used this method to discuss the perspectives of a group of eight of the participating students; also, their final reflections and opinions in terms of the whole process to promote critical reading through the use of political cartoons, the considerations of these topics inside the EFL classroom, and the discussions raised about social and political issues of Colombia. This instrument was applied at the end of the process. 


\section{Data Analysis}

I based the analysis on the grounded theory method, which looks to find new concepts, constructs, categories, and relationships established among them. Strauss and Corbin (1990) state that in grounded theory, theory emerges from the data collected through the implementation of an inductive process rather than a deductive one. Núñez and Téllez (2012) highlight the effectiveness of this approach, because "it involves the constant comparison of the data in order to group and classify them for the construction of a theory" (p. 63).

According to Glaser and Strauss (1967), analyzing the data requires a constant revision and reading of the information collected from the sources that were applied in the study. In this case, I decided to use the three instruments to collect the information: the students' artifacts gave me insights about their position and understanding in order to determine what the use of Colombian political cartoons reveals about the promotion of critical reading. The teacher journal provided me with data related to the reading strategies that the students used while they were involved in the practice of SCAMS technique to read cartoons. Finally, the focus-group interview expanded and clarified the data collected with the other instruments as well as informed what the students had experienced during the implementation of the project.

I based this data analysis on three principles of the grounded theory, as described by Strauss and Corbin (1998) and Urquhart (2013). For these authors, there are mainly three phases to analyze data. The first phase accounts for the first step which is the open coding. In this phase, I went through the data gathered and underlined all relevant information that was found in each of the instruments. I read and reviewed the data, then I classified the information by using charts in which I recorded the frequency of the answers and commented on what those answers could mean.

Then, I followed the next step which is central or axial coding in order to highlight and select the suitable information related to the research question of this study. In this phase, I identified relationships among the open codes and found some similarities in the different instruments used to collected data. Then, I proceeded to identify the common patterns and grouped them into concepts to make sense of them. I named them and could mainly identity two big categories; I established some subcategories for each one of the emerging codes. Figure 1 shows the name of the initial categories.In the last phase, theoretical or selective coding, I considered a number of theories and authors that supported the different categories and subcategories. "Theoretical coding is when we relate the codes to each other and look at the nature of the relationships between those codes" (Urquhart, 2013, p. 26). 

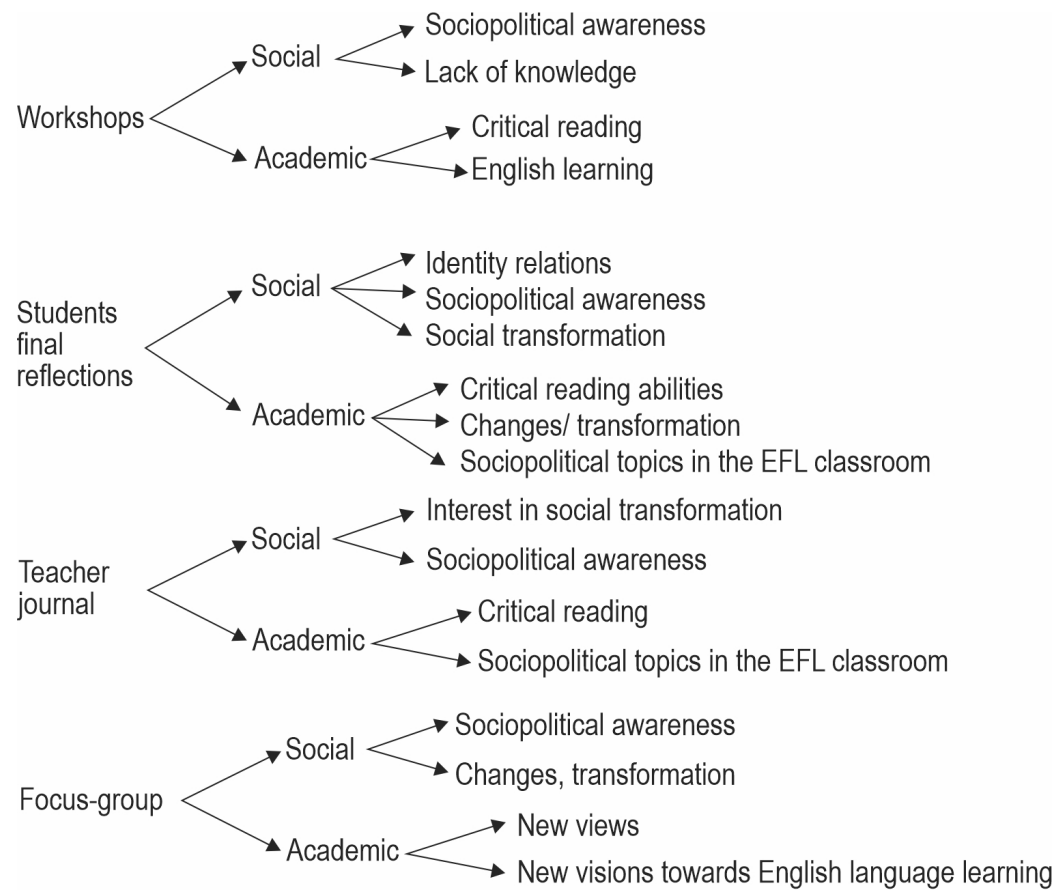

Figure 1. Example of Central Coding Process

In the process of indicating data, I used a number of codifications to identify the parts of the information from each collection instrument. To understand the source of the different excerpts in the section of Findings, I illustrate the codifications adopted in this study in the table below.

Table 2. Codifications of Instruments

\begin{tabular}{|l|l|}
\hline \multicolumn{1}{|c|}{ Codification } & \multicolumn{1}{c|}{ Meaning } \\
\hline FG & Focus group \\
\hline WS- 3 & Workshop No. 3 \\
\hline FR & Final Reflection \\
\hline TJ-2 & Teacher's journal \\
\hline Designer, Pickles, Chepe... & Pseudonym of students \\
\hline
\end{tabular}




\section{Findings}

In this section, I present the findings of the research study. These are divided into categories and subcategories. A number of excerpts were considered and analyzed to support the name of the emerging categories. These were related to the main question. I divided each category into two subcategories as shown in the following table.

Table 3. Emerging Categories and Subcategories

\begin{tabular}{|l|l|l|}
\hline \multicolumn{1}{|c|}{ Research Question and Sub-Question } & Categories & \multicolumn{1}{c|}{ Subcategories } \\
\hline $\begin{array}{l}\text { What does the use of Colombian } \\
\text { political cartoons reveal about } \\
\text { the promotion of critical reading } \\
\text { in students of an intermediate } \\
\text { English class at a private university? }\end{array}$ & $\begin{array}{l}\text { 1. A critical rea- } \\
\text { der inside and } \\
\text { outside the } \\
\text { classroom }\end{array}$ & $\begin{array}{l}1.1 \text { I am a social human: My world, } \\
\text { my country, my society, myself } \\
\text { The English classroom: A space } \\
\text { to see and transform reality }\end{array}$ \\
\hline $\begin{array}{l}\text { What reading strategies do students } \\
\text { use while they are involved in } \\
\text { the practice of the SCAMS } \\
\text { technique to read cartoons? }\end{array}$ & $\begin{array}{l}\text { 2. } \\
\text { Building the } \\
\text { pathway to be- } \\
\text { come a critical } \\
\text { reader }\end{array}$ & $\begin{array}{l}2.1 \text { Opening my mind } \\
2.2 \text { Establishing relationships }\end{array}$ \\
\hline
\end{tabular}

\section{A Critical Reader Inside and Outside the Classroom}

This category is closely related to the common concept of critical reading as stated by Freire and Macedo (1987). The different excerpts presented here were carefully selected because these are representative and meaningful for the study. The following excerpt portrays the importance of developing activities related to critical reading to generate changes.

It is important that we do this activities in the classroom, to make good actions in our house and society, in this way, we generate a positive change for the country and there will be a better future for all. [sic] (FR, Canelita)

When Canelita states that "it is important to develop these activities within the classroom and also to make good actions in the house or society," she intends to take what she learns in the classroom to her real life. This was one of her final reflections after the process finished. This excerpt relates to the idea of transformation from the classroom. 


\section{Am a Social Human: My World, My Country, My Society, Myself}

This first subcategory accounts for the exploration, description, and analysis of this study in relation to the social context. This subcategory emerged from one of the contexts where the students had changes: the social context. I found that the different activities carried out in the classroom helped the students to think, reflect and be more aware about the different social issues of their world. I was aware of this in the following entry of my teacher journal:

A student tells me that the failure in the plebiscite about the peace processes affected their community drastically, because they have had to live war for more than 20 years. She says that she thought that plebiscite was going to be the end of many years of violence. For her, it was frustrating that people who voted "NO" do not know or have not lived war as she has. [sic] (TJ-3)

Her opinion allows me to see that she has suffered war and is perhaps more conscious of this problem than those who have not lived it. Her situation, context, and experience made her become a person who thinks about how hard and frustrating it is to live surrounded by violence. In this respect, Sager (2013) says, "our realities are shaped by our context, and we need to be critical about this situation" (p. 9). The excerpt below portrays how the English language classroom is perceived in this institution.

The different images make part of our own culture and symbolize fundamental aspects of our daily life. However, these topics are rarely taken into account in the classroom. Maybe, people from Law and Political Science see these topics, but everybody should see them. [sic] (FR, Katepache)

Katepache is conscious of the importance of these topics within the classroom. When she expresses that everybody should study these topics, it allows me to think about the lack of opportunities that the students have had to make a critical exploration of these topics in the English language classroom. The following response highlights the importance of critical reading activities and the way that a research study like this fosters positive changes in students.

Perhaps we can't do too much against corruption, but education and project like this have taught me that through critical reading I can perceive these issues different and that the solution to those problems starts from me. Unfortunately, although you don't agree with the decisions that politicians make, you finally bave to accept them. So, we, young people can have the power to transform that reality. [sic] (WS-2, Pickles)

When Pickles refers to the important role that education plays when facing social and political issues, she makes it clear that knowledge and comprehension are possible ways to transform reality. However, critical reading demands from people the use of reading as a means to label the world from their own perspectives, then, to transform those social inequalities (Freire \& Macedo, 1987). This student clearly has a critical point of view, because 
she analyzes the way they can change people's minds towards the idea and concept of politics; this can be a starting point of transformation which may develop their choices for social change in the long run (Short, 1993).

\section{The English Classroom: A Space to See and Transform Reality}

This subcategory emerges from the information related to the academic context, the English classroom. Nowadays, with the emerging theory of decolonization proposed by some authors such as Walsh and Mignolo (2018), and Quijano (1998), having students reflect on "the political, economic and social environment in which they grow up" (Kumaravadivelu, 2006 , p. 174) becomes important. The excerpt below shows a number of positive patterns in regard to the English language class and activities developed during the process.

During the development of the activities, the teacher implemented a new methodology that I had not seen in any other class of English. The use of cartoons helped to wake up our brain and make it wonder about the possible and different ways to read and understand reality and give solution to the problems of the world. [sic] (FR, Rivers)

When Rivers states that the use of political cartoons helped him to "wake up" his brain and wonder about the different ways to understand reality in order to give solutions, the use of these tools in the classroom becomes paramount in order to contribute to the transformation of society. Awareness of social issues should be a topic considered in the English language classroom as stated in the next excerpt:

At the beginning it was weird for me to see these topics in the English class. Normally we see these topics in other subjects, but it was interesting to contribute with solutions of different problems from the class of English. It is a problem that affect everybody. [sic] (FG, Laupa)

In regard to what Laupa expresses in the interview after asking about the relationship between the English language class and sociopolitical topics, she mentions that social problems affect everybody and that these topics should also be considered in the English language classroom. This allows highlighting the crucial role of education when facing and treating sociopolitical issues.

\section{Building the Pathway to Become a Critical Reader}

This category is closely related to the process and reading strategies that the students used to read cartoons through a technique called SCAMS. The different activities that the students developed gave me, as the researcher, insights about the possible strategies that the students used when reading critically. In this category, two subcategories emerged: Opening my mind and establishing relationships. 


\section{Opening my Mind}

This subcategory arises from the transformation that the students made at the end of the study after having passed through different cognitive processes that allowed them to foster their critical reading. The name of this subcategory shows that it is closely related to one of the concepts of critical reading that Jurado (2008) proposes. For him, critical readers are characterized by being skeptic, not in the sense of not believing anything, but in the sense of being curious about the origin of the information they receive, and being open minded to the different messages that people communicate. The next excerpt illustrates what one of the participants thinks about the technique (SCAMS) used to analyze cartoons:

These scams are good to improve our intellectual capacity, are cool because we can give our opinion without fear to be judged, because we are free to express what we think or feel. [sic] (FG, Green Eyes)

When Green Eyes states that they can give their opinion without fear of being judged, it relates to the idea of being open minded as proposed by Kruglanski and Boyatzi (2012). This means being willing to listen to someone without judging them or jumping to conclusions before they have finished. When the student says "we can give our opinion without fear to be judged," one could think that either they rarely have the opportunity to express, or that expressing in Colombia may be seen as a fact to be judged. The response below shows the difficulty that is sometimes present as to reading and understanding cartoons:

Sometimes I don't read cartoons because I could not understand the messages that the author wanted to give us, but now I started to open my mind and leave the common perceptions I had towards this topic, I started to understand the messages. There were some cartoons that changed my mind a lot. [sic] (FG, Sebas)

Sebas states that reading some messages in political cartoons was hard for him at the beginning. Then, he says that one the strategies that he used in order to be able to understand those messages was to abandon the common perceptions that he had towards the cartoons and their topics; he had to open his mind to listen to and read the other. This fragment shows that promoting critical reading through political cartoons not only fosters social awareness in students, but also helps them learn to read actively and critically; furthermore, through the creations of their own written texts and cartoons, they could construct their own knowledge. The technique implemented to analyze cartoons was a good source for reading these from a critical perspective as stated in the following excerpt:

With the implementation of SCAMS, although you know how to read them, it requires that people analyze well what the title, or an expression, or an image want to say. My thinkings changed and now I consider I am more critical with respect to the social and political topics of my country. [sic] (FG, Drawer)

By reading and analyzing the excerpt above, I can notice that his thoughts changed, as he now considers himself a more critical person. The way he had to be very open minded 
in order to become what he is now is noticeable, as well as the way he thinks and reads his world as regards social and political issues.

The word now clearly means that he might consider himself acritical before the study. This reinforces the idea that promoting critical reading in education through political cartoons fosters students' becoming more aware of the different social and political problems of their society. Next excerpt shows a number of perceptions described by the researcher-author at the end of the process.

This is the last session and this time they are not using SCAMS. However, I can see that the way they reflect about the different problems is different. It seems they are more aware about social and political topics. Although there is a different interpretation, their ideas and arguments are more critical, deeper and stronger, generating awareness and new knowledge about these topics. [sic] (TJ-4)

\section{Establishing Relationships}

This subcategory emerges as one of the strategies that the students used the most while doing the activities; this also has to do with how the students established relationships among segments their reality, their own experiences, and the text. The following excerpt illustrates feelings, thoughts and perceptions of students registered by the researcher during one of the sessions.

Students are told to discuss about corruption stories they know in their towns, cities or departments. They seem to be worried and sad to realize about how money is stolen in this country. They argue that the future depends on the kind of professionals they will be and that they cannot only complain about the corruption, but to fight against it. They say that they did not realize about the big social and political problems of this country, till they started to study these issues deeper. All of them think about different ways to finish with this problem that they say is getting worse and nobody does anything. [sic] (TJ-2)

During this activity, the students had to discuss their own experiences in relation to corruption and their reality as students in order to be able to understand the text and be able to read it critically. Their commitment to contribute with solutions, the responsibility they had as students and future professionals took them to decode the messages hidden in the different images of the cartoons. The following excerpt shows a number of patterns related to social awareness, the English language classroom, and critical perspectives:

With the development of these activities we acquire new skills to learn new words, write texts in English and others. Also, one thinks more about the life that one lives in this country, about the education we have received, the problems of corruption, health, etc. and how from our career and from own actions we can manage to solve these problems. All these things help to understand the text from a more critical perspective. [sic] [FG, Designer) 
Being critical and aware of the different social and political problems of the world does not only mean to talk about transformation. It requires that people start not only thinking but also acting differently. In this sense, Giroux (2004) indicates that:

Part of the challenge of linking critical pedagogy with the process of democratization suggests constructing new locations of struggle, vocabularies, and subject positions that allow people in a wide variety of public spheres to become more than they are now, to question what it is they have become within existing institutional and social formations, and to give some thought to what it might mean to transform existing relations of subordination and oppression (p. 35).

The above quote shows the effectiveness of the activities developed in class to think and reflect more about what happens around us. In the interview, Katepache states that it is easier to reflect on social and political issues because experiences are analyzed in relation to reality:

It is excellent to strengthen socio-political awareness through these types of tools, since they are not boring or tedious. These activities tend to remain more easily in memory, because one puts own experiences at stake, and see how those experiences are related to reality and that helps to think and reflect on how to make better decisions for the country. [sic] (FG, Katepache)

The relationship among the reader's experiences, reality, and the text helps to shape the notion of critical reading from the reader's perspective, which is a basis for the construction of meaning and new knowledge. According to Jurado (2008), readers hardly develop critical reading because they rarely use strategies that can take them to observe and analyze their own reality, their prior knowledge and their own life experiences.

\section{Conclusions}

The analysis of the different data showed significant information in order to describe what the use of political cartoons revealed about the promotion of critical reading in an EFL classroom. The implementation of political cartoons seemed to be a great and useful pedagogical strategy to achieve this objective. Also, the examination of the different information collected for this current study showed that the different activities and processes carried out in the EFL classroom helped enhance the way the participating students read the world.

In that sense, I found that the use of political cartoons to foster critical reading brought changes mainly in two different but connected contexts: the academic and the social contexts. The students highlighted the importance of treating sociopolitical issues in the EFL classroom. This may be a big step to start seeing the English language not only as system but also as a means of communication and contact with the world. The transition from being a non-critical reader to becoming a critical reader took time, awareness, commitment, good habits, and being willing to be a different human, student, and future professional. 
Colombian reality was brought into the English language classroom, where we as English teachers are many times in charge of considering other foreign cultures instead of using our culture and local context. I found a different way to create critical awareness in my students via political cartoons as well as to make them different readers of everything they see around them.

\section{Pedagogical Implications}

Critical reading requires a curious, probing stance towards both texts and contexts, where readers can understand, interpret, and establish relationships between what they read and their own reality. Based on the findings of this study, English became a different subject for the students and even for myself, as both a language teacher and researcher. For them, they practiced different skills and learnt new vocabulary related to social and political issues. In the same way, they fostered their social skills when listening to others and working in groups. For me, integrating the language skills and considering social issues in the EFL classroom were interesting teaching actions.

Finally, I now believe that this kind of topics, social and political issues, should become part of the English syllabuses of the different educative institutions. Nowadays, it is seen that the world is suffering in ecological, social, political, and cultural issues, among others. Thus, educating students to be aware of the different problems of their society becomes necessary in order for them to contribute with solutions. I suggest not forgetting that problems in education also make up part of political issues and that any teacher is called upon to empower students so that they can become critical humans, conscious of what they read in texts and in their contexts.

\section{References}

Ammons, D., King, J., \& Yeric, J. (1988). Unapproved image makers: Political cartoonists' topic selection, objectivity and perceived restrictions. Newspaper Research Journal 9(3), 79-90.

Barrow, R., \& Wood, R. (2007). An introduction to philosophy of education (4 ${ }^{\text {th }}$ ed.). Routledge.

Bell, J. (1993). Doing your research project. A guide for first- time researchers in Education and Social Science. Open University Press.

Bloom, B. (1956). Taxonomy of educational objectives, Handbook. I: The cognitive domain. David McKay Co. Inc.

Bosley, L. (2008). 'I don't teach reading': Critical reading instruction in composition courses. Literacy Research and Instruction, 47(4), 285-308.

Buitrago, C. (2010). Reading circles as a critical reading practice [Unpublished master's dissertation]. Universidad Pedagógica y Tecnológica de Colombia. 
Cortés, A. \& Rativa, A. (2015). Arqueología de la pedagogía crítica en Colombia: 1980 - 1990 [Undergraduate monograph]. Universidad Pedagógica y Tecnológica de Colombia.

Crookes, G., \& Lehner, A. (1998). Aspects of process in a critical pedagogy teacher education course. TESOL Quarterly, 32(2), 319-328.

Denzin, N. K., \& Lincoln, Y. S. (2005). The Sage handbook of qualitative research (3 ${ }^{\text {rd }}$ ed.). Sage Publications.

Domínguez, C. (2017). Raising critical awareness of the linguistic landscape: An experience with a group of EFL pre-service teachers in Colombia [Master dissertation]. Universidad de Antioquia.

Dougherty, B. (2002). Comic relief: Using political cartoons in the classroom. International Studies Perspectives, 3, 258-270.

Echeverri, P. (2020). Critical pedagogy and L2 education in the Global South. L2 Journal, 12(2), 21-33.

Freeman, D. (1998). Doing teacher- research: From inquiry to understanding. Heinle \& Heinle Publishers.

Freire, P., \& Macedo, D. (1987). Literacy: Reading the word and the world. Bergin \& Garvey.

Glaser, B., \& Strauss, A. (1967). The discovery of grounded theory: Strategies for qualitative research. Aldine Publishers.

Giroux, H. (2004). Critical pedagogy and the postmodern/modern divide: Towards a pedagogy of democratization. Teacher Education Quarterly, 31(1), 31-47.

Halliday, M., \& Hasan, R. (1976). Cohesion in English. Longman.

Hancock, D., \& Algozzine, B. (2006). Doing case study research: A practical guide for beginning researchers. Teachers College, Columbia University.

Huang, S. (2011). Reading "further and beyond the text": Student perspectives of critical literacy in EFL reading and writing. Journal of Adolescent \& Adult Literacy, 55(2), 145-154.

Hudelson, S. (1994). Literacy development of second language children: Educating second language children: The whole child, the whole curriculum, the whole community. Cambridge University Press.

Jurado, F. (2008). La formación de lectores críticos desde el aula. Revista Iberoamericana de Educación, $46,89-105$.

Kaura, S., \& Sidhub, G. (2013). Evaluating the critical literacy practices of tertiary students. Procedia - Social and Behavioral Sciences, 123, 44-52.

Kruglanski, A., \& Boyatzi, L. (2012). The psychology of closed and open mindedness, rationality, and democracy, Critical Review. A Journal of Politics and Society, 24(2), 217-232. https://www. doi.org/10.1080/08913811.2012.711023

Kumaravadivelu, B. (2006). Understanding language teaching: From method to post-method. ESL \& Applied Linguistics Series.

Mackay, J. (2017). What does society owe political cartoonists? Journalism Studies, 18(1), 28-44. https://www.doi.org/10.1080/1461670X.2016.1218297 
Martinez, S. L. (2011). Political Cartoon. Online. http://lucindasierra-politicalcartoons.blogspot. com/2011/06/political-cartoons.html

McLaren, P. (2003). Critical pedagogy and class struggle in the age of neoliberal globalization: Notes from history's underside. Democracy \& Nature, 9(1), 65-90.

McMillan, J., \& Schumacher, S. (2000). Research in education. A conceptual introduction (5 ${ }^{\text {th }}$ ed.). Longman.

Merriam, S. (1991). Case study research in education: A qualitative approach. Jossey-Bass Publishers.

Michelson, K., \& Álvarez, J. (2016). Study abroad: Tourism or education? A multimodal social semiotic analysis of institutional discourses of a promotional website. Discourse \& Communication, 10(3), 235-256.

Núñez, A., \& Tellez, M. (2012). Using debates in the classroom: A pedagogical strategy for the development of the argumentative competence in the teaching of English as a foreign language. Departamento de Publicaciones, Universidad Externado de Colombia.

Ortega, P. (2009). Critical Pedagogy: Reflections on its practices and challenges. Pedagogía y Saberes, 31, 26-34.

Park, Y. (2011). Using news articles to build a critical literacy classroom in an EFL setting. TESOL Journal, 2(1), 24-51.

Quijano, A. (1998). Colonialidad del poder, cultura, y conocimiento en América Latina. Ecuador Debate CAAP, 44, 227-238.

Ramos, B., \& Aguirre, J. (2011). Fostering skills to enhance critical educators: A pedagogical proposal for pre-service teachers. HOW, 18(2), 169-197.

Sager, M. (2013). Understanding the hidden curriculum: Connecting teachers to themselves, their students, and the earth. Portland State University.

Samacá, Y. (2012). On rethinking our classrooms: A critical pedagogy view. HOW, 19(2), 194-208.

Short, K. (1993). Making connections across literature and life. Children Responding to Literature. Heinemann.

Stake, R. (1995). The art of case study research. Sage Publications.

Strauss, A., \& Corbin, J. (1990). Basics of qualitative research: Grounded theory procedures and techniques. Sage Publications.

Strauss, A., \& Corbin, J. (1998). Basics of qualitative research: Techniques and procedures for developing grounded theory. Sage Publications.

Urquhart, C. (2013). Grounded theory for qualitative research: Practical guide. Sage.

Wallace, C. (2003). Critical reading in language education. Palgrave Macmillan.

Walsh, C., \& Mignolo, W. (2018). On decoloniality. Analytics praxis. Duke University Press.

Yin, K. (2016). Qualitative research from start to finish (2 $2^{\text {nd }}$ ed.). Guilford Publications.

Zyngier, S., \& Fialho, O. (2010). Pedagogical stylistics, literary awareness, and empowerment: A critical perspective. Language and Literature, 19(1), 13-33. 